\title{
STRAIN VARIATION IN THE INFECTIVITY OF SCHISTOSOMA MANSONI FOR BIOMPHALARIA GLABRATA(1)
}

\author{
Luiz Candido de Souza DIAS (2), John I. BRUCE (3) \& Gerald C. COLES (4)
}

\section{SUMMARY}

Five strains of Schistosoma mansoni resistant and susceptible to schistosomicides were studied for infectivity of 2 strains of Biomphalaria glabrata one of Puerto Rican origin and the other of Brazilian origin.

Puerto Rican strains of $\mathbf{S}$. Mansoni developed more slowly and had a lower infec tivity in Brazilian B. glabrata than did the Brazilian S. mansoni. However, Brazilian S. mansoni developed as well in Puerto Rican snails as in Brazilian snails, indicating that drug resistant strains could easily be moved by travel of infected persons from one area to another.

KEY WORDS: Schistosoma mansoni; Biomphalaria glabrata; Strains, Experimen tal infectivity.

\section{INTRODUCTION}

It is well known that geographic strains of schistosomes vary in infectivity for their host snails $^{2,6,12-22}$. This is of importance not only for the introduction of schistosomes in to previously uninfected areas, but because of the potential for the spread of drug resistant strains of worms.

The present study was undertaken to determine if drug resistant strains of $\mathbf{S}$. mansoni from Brazil and Puerto Rico were infective to Biomphalaria glabrata from the two countries. As these snails came from both the most northern (Puerto Rico) and the most southern (Brazil) points of their geographic ranges, the information would indicate how far the host parasite relationship has diverged.
MATERIALS AND METHODS

\section{Snail Strains.}

B. glabrata, an albino strain of Puerto Rican origin, has been maintained continuously in laboratory cultivation since 1953 (24 years at the University of Michigan and 10 years at the Center for Tropical Diseases, University of Lowell, U.S.A.).

B. glabrata an albino strain from Minas Gerais State, Brazil and of known susceptibility to S. mansoni has been maintained continuously in the laboratory for more than 20 years in the

(1) This study was supported in part by the Research Foundation of São Paulo State (FAPESP), Brazil and NIAID Grant n. 1R21-AI-20171-01 to the Center for Tropical Diseases, University of Lowell, Lowell, Massachusetts, U.S.A.

(2) State University of Campinas, Department of Parasitology. CP 6109. CEP 13081, Campinas, São Paulo, Brazil.

(3) Center for Tropical Diseases, College of Pure and Applied Science, University of Lowell, Lowell, Massachusetts 01854, U.S.A

(4) Department of Zoology, University of Massachusetts, Amherst, Massachusetts 01003, U.S.A. 
DIAS, L. C. de S.: BRUCE, J. I. \& COLES, G. C. - Strain variation in the infectivity of Schistosoma mansoni for Biomphalaria glabrata. Rev. Inst. Med. trop. São Paulo, 30 (2): 86 90, 1988.

Department of Parasitology, State University of Campinas, Brazil.

\section{Strains of Parasites}

BH (Belo Horizonte, Minas Gerais, Brazil).

This strain was isolated by PARAENSE \& CORR $\hat{\mathbf{E}} \mathbf{A}^{16}$ from an untreated patient who contracted the infection at Belo Horizonte. Since 1967 we have been maintaining this strain continuously in the laboratory by passage through albino $\mathbf{B}$. glabrata (Brazilian strain) and Swiss albino mice.

MAP (Minas Gerais, Brazil; oxamniquine and hycanthone resistant).

The MAP strain was obtained from a patient in $1978^{7}$ following unsuccessful treatment with hycanthone and then oxamniquine. This strain has been maintained continuously in the laboratory by passage through albino B. glabrata (Brazilian strain) and Swiss albino mice.

H-30 (Johns Hopkins, Puerto Rico; hycanthone resistant).

This strain was derived by in vivo selection in mice treated with hycanthone in $1976^{8}$ and has been maintained continuously in the laboratory by passage through B. glabrata (Puerto Ri- . can strain) and $C_{1}$ Swiss albino mice.

MPROXR (University of Massachusetts, Puerto Rico; oxamniquine resistant).

This strain was derived by in vitro selection of the MPR-1 strain ${ }^{5}$ with oxamniquine and has been maintained continuously in the laboratory by passage through B. glabrata (Puerto Rican strain) and $C_{1}$ Swiss albino mice since its selection in 1985 .

MPROL (University of Massachusetts, Puerto Rico).

This strain was derived by in vitro selection of the MPR-1 strain ${ }^{5}$ with oltipraz and has been maintained continuously in the laboratory by passage through B. glabrata (Puerto Rican strain) and $\mathrm{CD}_{1}$ Swiss albino mice since its selection in 1985.

Each of these strains are currently maintained at the Center for Tropical Diseases, University of Lowell. The MAP and BH strains are also maintained at the Department of Parasitology, State University of Campinas.

The present study was carried out in the Center for Tropical Diseases, University of Lowell.

\section{EXPERIMENTAL DESIGN}

Breeding and Maintenance of Snails.

The procedures used for cultivation and maintenance of snails and parasite were adopted from BRUCE \& RADKE ${ }^{1}$ and LIANG ${ }^{9}$.

\section{Collecting Miracidia.}

The method used for collecting miracidia was adopted from LIANG, BOYD \& BRUCE ${ }^{10}$. Eggs were collected from feces of mice with patent infection of 60 days or more. A group of ten mice were allowed to defecate on saline damper paper towels placed on the bottom of the excreta pan of their cage. The feces were removed and mixed throughly with $100 \mathrm{ml}$ of $0.85 \%$ saline. The suspension was poured into a tiered column of sieves arranged in descending order of mesh openings $(420 \mu, 177 \mu, 105 \mu$ and $45 \mu)$. The eggs were washed through to the bottom sieve with 100 $\mathrm{ml}$ of $0.85 \%$ saline. A volume of $100 \mathrm{ml}$ of aerated tap water was poured into the sieve column to rinse eggs free from saline. The eggs were washed from the bottom sieve into a petri dish ( $2 \times 10$ $\mathrm{cm}$ ) with $40 \mathrm{ml}$ of aerated tap water and concentrated to the center of the dish by gentle rotation. The eggs were then pipetted into a small dish $(1.5 \times 6 \mathrm{~cm})$ and the dish was placed under ceiling illumination to induce hatching of miracidia. $\mathrm{Mi}$ racidia usually appeared within $10 \mathrm{~min}$. Snails were exposed to miracidia which were less than one hour old.

\section{Exposure of Snails}

Snails (3-4 $\mathrm{mm}$ in size) were recovered from petri dish cultures and were exposed individu- 
DIAS, L. C. de S.; BRUCE, J. I. \& COLES, G. C. - Strain variation in the infectivity of Schistosoma mansoni for Biomphalaria glabrata. Rev. Inst. Med. trop. São Paulo, 30 (2): 86-90, 1988.

ally. Snails were placed in glass vials $(15 \times 17$ $\mathrm{mm}$ ) containing $0.2-0.4 \mathrm{ml}$ of aerated tap water. Each snail was exposed to 10 miracidia. The exposure temperature was $25-27^{\circ} \mathrm{C}$ and snails were left for 4 hours in the exposure containers under ceiling illumination. For each strain of S. mansoni, groups of 50 snails were exposed. Corresponding control groups (B. glabrata from Brazil and Puerto Rico) also consisted of 50 snails.

After exposure snails were maintained in groups of 25 per plastic tray containing 1.5 liters of aerated tap water and supplied with lettuce, blue-green algae, and mud. They were placed under continuous light, and the trays were changed weekly until they were screened for infection.

\section{Determination of Infection.}

Daily observations were made for mortality throughout the experimental period (70 days). Snails were individually examined for the pre sence of infection at 21 days after exposure and thereafter at intervals of 7 days. To check for infection, snails were placed under total dark ness for eight hours. Thereafter, the snails were placed in a $2.0 \times 3.0 \mathrm{~cm}$ glass vial containing
$4.0 \mathrm{ml}$ of filtered aerated tap water, exposed to bright illumination for three hours and exami ned for the presence of cercariae using a dissec ting microscope. Snails found to be initially ne gative for infection were also examined at intervals of 7 days. At the end of the experimental period those snails which were never found to be positive for infection were crushed and their digestive glands examined for the presence of sporocyst development.

According to the available data obtained from the periods of infection divided in 0-28 days (pre-patent) and 29-70 days (patent), the snail mortality and the percentage of snails shedding cercariae we could evaluate the susceptibility of B. glabrata to different strains of S. mansoni.

The infection with sympatric strains of Puerto Rican snails and S. mansoni will be study in future works.

\section{RESULTS AND DISCUSSION}

The data obtained is shown in Table 1. It was confirmed that snails failing to shed cerca riae did not contain schistosome larval stages.

TABLE 1

Susceptibility of Biomphalaria glabrata from Brazil and Puerto Rico to Different Strains of Schistosoma mansoni

\begin{tabular}{|c|c|c|c|c|c|c|c|c|c|}
\hline \multirow{4}{*}{$\begin{array}{l}\text { Snail } \\
\text { Strain }\end{array}$} & \multirow{4}{*}{$\begin{array}{l}\text { Schistosome } \\
\text { Strain }\end{array}$} & \multicolumn{8}{|c|}{ Days of Infection } \\
\hline & & \multicolumn{4}{|c|}{$0-28$ days } & \multicolumn{4}{|c|}{$29-70$ days } \\
\hline & & \multicolumn{2}{|c|}{ Deaths } & \multicolumn{2}{|c|}{$\begin{array}{l}\text { Shedding } \\
\text { Cercariae }\end{array}$} & \multicolumn{2}{|c|}{ Deaths } & \multicolumn{2}{|c|}{$\begin{array}{l}\text { Shedding } \\
\text { Cercariae }\end{array}$} \\
\hline & & $\overline{\mathrm{N}}$. & $\%$ & N? & $\%$ & $\mathrm{~N}$ ? & $\%$ & N: & $\%$ \\
\hline \multirow[t]{6}{*}{ Brazilian } & $\mathrm{BH}$ & 4 & 8 & 0 & 0 & 21 & 42 & 41 & 82 \\
\hline & MAP & 1 & 2 & 11 & 22 & 11 & 22 & 29 & 58 \\
\hline & $\mathrm{H}-30$ & 0 & 0 & 0 & 0 & 1 & 2 & 8 & 16 \\
\hline & MPROL & 0 & 0 & 0 & 0 & 1 & 2 & 5 & 10 \\
\hline & MPROXR & 0 & 0 & 0 & 0 & 1 & 0 & 4 & 8 \\
\hline & Control & 0 & 0 & 0 & 0 & 0 & 0 & 0 & 0 \\
\hline \multirow{3}{*}{$\begin{array}{l}\text { Puerto } \\
\text { Rican }\end{array}$} & $\mathrm{BH}$ & 0 & 0 & 0 & 0 & 43 & 86 & 45 & 90 \\
\hline & MAP & 1 & 2 & 4 & 8 & 17 & 34 & 46 & 92 \\
\hline & Control & 1 & 2 & 0 & 0 & 0 & 0 & 0 & 0 \\
\hline
\end{tabular}

Obs: each exposure group contained 50 snails. 
DIAS, L. C. de S.; BRUCE, J. I. \& COLES, G. C. - Strain variation in the infectivity of Schistosoma mansoni for Biomphalaria glabrata. Rev. Inst. Med. trop. São Paulo, 30 (2): 86-90, 1988.

The results show the occurrence of a slower rate of development as well as lower infectivity of the Puerto Rican derived strains of S. mansoni than the two Brazilian schistosome isolates for the Brazilian strain of snail.

These differences may indicate that a significant divergence in properties of the two schistosome strains has occurred. Despite these differences, infections did occur with the drug resistant strains suggesting that resistance could travel with the movement of people who were not cured following therapy. Movement of breeding stock has been suggested as one method in the spread of drug resistant ovine nematodes ${ }^{4}$. By contrast to the lowered susceptibility of the Brazilian snails to the Puerto Rican S. mansoni, the Puerto Rican snails were much more susceptible to the Brazilian S. mansoni.

It would be of interest to know how fast the drug resistant strains of $\mathbf{S}$. mansoni from Puerto Rico would adapt to the Brazilian snails if transmission only occurred through this strain of snail. It would also be relevant do determine how fresh isolates from patients from the two geographic regions differ in their infectivity to the two strains of snails. The difference in infectivity re ported here might represent long term passage through mice in the laboratory. It is known that passage through mice can affect biochemical properties of the worms ${ }^{3,}{ }^{11}$. The infectivity of recently isolated drug resistant strains of $\mathbf{S}$. mansoni in Brazil should be investigated further for their infectivity to a range of potential intermediate hosts, both within Brazil and from other countries.

\section{RESUMO}

Suscetibilidade de linhagens de Biomphalaria glabrata a cepas de Schistosoma mansoni

Com duas linhagens de Biomphalaria glabrata foi estudada a suscetibilidade de cinco cepas de Schistosoma mansoni resistentes e suscetíveis a esquistossomicidas. Três cepas do trematódeo oriundas de Porto Rico apresentaram desenvolvimento mais lento e menor índice de infecção em B. glabrata brasileira quando comparados com o comportamento de duas cepas de
S. mansoni provenientes do Brasil. Por outro lado, as cepas brasileiras do parasita desenvolveram bem e infectaram mais de $90 \%$ dos exem. plares de B. glabrata portorriquenhos. Entre os resultados, ressalta-se que cepas resistentes a esquistossomicidas poderão ser introduzidas por pacientes em diferentes áreas geográficas como Brasil e Porto Rico.

\section{ACKNOWLEDGEMENTS}

We are grateful to Dr. Yung-san Liang for his helpful suggestions and to Mr. David A. Boyd and Ms. Deborah M. Russell for their valuable technical assistance, and to Ms. Allison M. Ho ward for typing the manuscript. Support for this study was provided in part by the Research Foundation of São Paulo State (FAPESP), Brazil and by Grant № 1R21-AI-20171-01 from the National Institute of Allergy and Infectious Diseases (NIAID), National Institutes of Health (NIH), United States of America.

\section{REFERENCES}

1. BRUCE, J. I. \& RADKE, M - Culturing Biomphalaria and Oncomelania (Gastropoda) for large scale studies of schistosomiasis. I. Cultivation of Biomphalaria glabrata and maintenance of Schistosoma mansoni in the laboratory. Bio-Medical Reports of the 406th Medical Laboratory, 19: 1-84, 1971.

2. BASCH, P. F. - Intermediate host specificity in Schistosoma mansoni. Exp. Parasit. 39: 150-169, 1976.

3. COLES, G. C. - Alteration of Schistosoma mansoni malate dehydrogenase isoenzymes on passage in the labora tory. Comp. Biochem. Physiol., 40B: 1079-1083, 1971.

4. COLES, G. C. - Anthelmintic resistance in sheep. In: HUD, R. P.; SIBBS, H. C. \& MURRELL, K. D., ed. Veterinarian clinics of North America, food animal practices. Philadelphia, W. B. Saunders, 1986. v. 2. p. 423-432.

5. COLES, G. C. \& BRUCE, J. I. - In vitro selection of drugresistant Schistosoma mansoni. Int. J. Parasit., 17: $767-77.1,1987$.

6. CRAM, E. B. - Evidence concerning geographic strains of human schistosomes and their molluscan hosts. Thapar Commemoration Volume. Lucknow, University of Lucknow, 1953. p. 51-62.

7. DIAS, L. C. S.; PEDRO, R. J.; RIGO, E.; GOTO, M. M. F. \& MAFRA, G. L. - Linhagem humana de Schistosoma mansoni resistente a esquistossomicidas. Rev. Saúde publ. (S. Paulo), 12: 110, 1978. 
DIAS, L. C. de S.; BRUCE, J. I. \& COLES, G. C. - Strain variation in the infectivity of Schistosoma mansoni for Biomphalaria glabrata. Rev. Inst. Med. trop. São Paulo, 30 (2): 86-90, 1988.

8. JANSMA, W. B.; ROGERS, S. H.; LIU, C. C. \& BUEDING E. - Experimentally produced resistance of Schistosoma mansoni to hycanthone. Amer. J. trop. Med. Hyg., 26: 926-936, 1977.

9. LIANG, Y.S - Cultivation of Bulinus (Physopsis) globosus (Morelet) and Biomphalaria pfeifferi pfeifferi (Krauss), snail hosts of schistosomiasis. Sterkiana, 7 : $53,54,1974$.

10. LIANG, Y.S.; BOYD, D. A. \& BRUCE, J. I. - Maintenance of Schistosome Cycles (Schistosoma mansoni, S. haematobium and $S$. japonicum). Unpublished.

11. LOVERDE, P. T.; DEWALD, J.; MINCHELLA, D. J .; BOS SHARDT, S. C. \& DAMIAN, R. T. - Evidence for host-induced selection in Schistosoma mansoni. J. Parasit., 71: 297-300, 1985.

12. MICHELSON, E. A. \& DUBOIS, L. - Susceptibility of Bahian populations of Biomphalaria glabrata to an allopatric strain of Schistosoma mansoni. Amer. J. trop. Med. Hyg., 27: 782-786, 1978.

13. MICHELSON, E A. \& DUBOIS, L. - An isoenzyme marker possibly associated with the susceptibility of Biomphalaria glabrata populations to Schistosoma mansoni. Acta trop. (Basel), 38: 419-426, 1981

14. MULVEY, M. \& VRIJENHOEK, R. C. - Genetic variation among laboratory strains of the planorbid snail Biomphalaria glabrata. Biochem. Genet., 19: 1169-1182, 1981
15. NEWTON, W. L. - The establishment of a strain of Australorbis glabratus which combines albinism and high susceptibility to infection with Schistosoma mansoni. J. Parasit., 41: $526-528,1955$.

16. PARAENSE, W. L. \& CORREA, L. R. - Variation in sus ceptibility of Australorbis glabratus to a strain of Schistosoma mansoni. Rev. Inst. Med. trop. S. Paulo, 5: 15-22, 1963.

17. RICHARDS, C. S. - Susceptibility of adult Biomphalaria glabrata to Schistosoma mansoni infection. Amer. J. trop. Med. Hyg., 22: 748-756, 1973

18. RICHARDS, C. S. - Genetic factors in susceptibility of Biomphalaria glabrata for different strains of Schistosoma mansoni. Parasitology, 70: 231-241, 1975.

19. RICHARDS, C. S. \& MERRITT JR., J. W. - Genetic factors in the susceptibility of juvenile Biomphalaria glabrata to Schistosoma mansoni infection. Amer. J. trop. Med. Hyg, 21: 425-434, 1972 .

20. VOGEL, H. - Infektionsversuche an verschiedenen $\mathrm{Bi}$ lharzia-Zwischenwirten mit einem einzelnen Mirazidium von Bilharzia mansoni und B. japonica. Zbl. Bakt., 148: $29-35,1941$.

21. WRIGHT, C. A. - Relationships between schistosomes and their molluscan hosts in Africa. J. Helminth., 40: $403-412,1966$

22. WRIGHT, C. A.; FILE, S. K. \& ROSS, G. C. - Studies on the enzyme systems of planorbid snails. Ann. trop. Med. Parasit., 60: 522-525, 1966.

Recebido para publicação em 21/12/1987. 